Arch Virol (1988) 103: 27-33

Archives

Vírology

(C) by Springer-Verlag 1988

\title{
Analysis of cell fusion induced by bovine coronavirus infection
}

\author{
H. R. Payne and J. Storz \\ Department of Veterinary Microbiology and Parasitology, Louisiana State University, \\ Baton Rouge, Louisiana, U.S.A.
}

Accepted August 12, 1988

Summary. Polykaryon formation in bovine fetal spleen (BFS) cells infected with bovine coronavirus L9 occurred only in media supplemented with trypsin. A single 1 to $2 \mathrm{~h}$ trypsin treatment $10 \mathrm{~h}$ and later after infection induced formation of polykaryons. Trypsin treatment at $\mathrm{pH} 7.5$ and 8.0 induced polykaryons while treatments at lower or higher $\mathrm{pH}$ levels did not. Cell fusion activity was partially suppressed by the presence of antibody.

\section{Introduction}

Infection of animal cells by enveloped viruses involves fusion between the viral envelope and a cell membrane. The fusogenic potential of viruses was studied in vitro with systems using erythrocytes, cultured cells, and liposomes as target membranes $[5,7,16,18,19]$. Membrane fusion is induced by paramyxoviruses at neutral $\mathrm{pH}$, which implies that these viruses enter the host cell by fusion of the viral envelop with the plasma membrane at the cell surface $[1,2]$. In contrast, cell fusion activities of Semliki Forest virus, influenza virus, and vesicular stomatitis virus strictly depend on acidic $\mathrm{pH}$ levels $[3,4,17,18]$. Low $\mathrm{pH}$ is used experimentally to simulate conditions existing within the acidic intracellular vesicles where penetration by these viruses is thought to occur.

Cell fusion and polykaryon formation in cultures infected with bovine coronavirus $(\mathrm{BCV})$ occur late in the virus replication cycle. In some types of host cells, polykaryocytosis is dependent on the presence of trypsin during the course of BCV replication [14]. The membrane events of virus-induced cell fusion and virus-cell fusion during entry appear to be based on the same principle [8]. The mode of BCV penetration of the host cell has not been clearly defined. We analyzed the trypsin-dependent cell fusion of BCV-infected BFS cells and found that the range of $\mathrm{pH} 7.5$ to 8.0 was optimal for polykaryon formation. 


\title{
Materials and methods
}

\author{
Virus and cells
}

Stock preparations of the Mebus strain L9 of BCV [12] were propagated in the human rectal tumor cell line HRT-18 [9]. Virus stocks were generated from cells infected at a multiplicity of $0.01 \mathrm{PFU}$ per cell, incubated for 4 to 5 days at $37^{\circ} \mathrm{C}$ in Dulbecco's modified Eagle medium (DMEM) buffered with $44 \mathrm{mM} \mathrm{NaHCO}_{3}$, and harvested by freeze-thawing. Viral titers in these preparations ranged from $10^{6}$ to $10^{7} \mathrm{PFU}$ per ml. The D 2 strain of BFS cells was maintained in minimal essential medium (MEM) buffered with $25 \mathrm{mM}$ HEPES and supplemented with $10 \%$ fetal calf serum.

\section{Effect of trypsin and trypsin inhibitors}

Cell monolayers were grown in $25 \mathrm{~cm}^{2}$ flasks to analyze the effects of trypsin and trypsin inhibitors on $\mathrm{BCV}$ replication. The cells were inoculated with $\mathrm{BCV}$ at a multiplicity of 2 PFU per cell, incubated in MEM containing trypsin ( 0.4 ug per ml; Sigma Chemical Company) treated with L-1-tosylamide-2-phenylethyl chloromethyl ketone, an inhibitor of chymotrypsin activity. Trypsin-treated and untreated cultures were also exposed to soybean trypsin inhibitor $(0.4 \mu \mathrm{g}$ per ml; Sigma Chemical Company) during the period of trypsin treatment. After $24 \mathrm{~h}$, the cultures were subjected to two freeze-thaw cycles and disrupted on ice by sound treatment (Branson Sonic Power Company) for $30 \mathrm{sec}$ to release the virus. Virus yields were determined by plaque assays and hemagglutination assays.

\section{$B C V$-induced polykaryon formation}

Monolayers of BFS cells were grown in 24-well plates for analysis of virus-induced polykaryon formation. Cultures infected at a multiplicity of $20 \mathrm{PFU}$ per cell were maintained in MEM with and without the addition of $0.4 \mu \mathrm{g}$ of soybean trypsin inhibitor per ml. The cultures were incubated for $26 \mathrm{~h}$ of infection, fixed for $10 \mathrm{~min}$ in Bouin's fixative and stained with Giemsa. The cells were examined microscopically with a $25 \mathrm{X}$ objective, and the extent of cell fusion was scored by counting the number of polykaryons with 4 or more nuclei in 5 randomly selected fields.

Experiments were conducted to identify the time period during which fusion of BCVinfected BFS cells is mediated by trypsin. Each infected monolayer was exposed to trypsin for 1-, 2-, or 4-h intervals during the period of virus replication. After $26 \mathrm{~h}$, the monolayers were fixed, stained, and scored for polykaryon formation.

\section{Effect of $p H$ on $B C V$-induced cell fusion}

The effects of various $\mathrm{pH}$ levels on polykaryon formation were determined. The monolayers were infected as described above and incubated in MEM buffered with $10 \mathrm{mM}$ HEPES and $10 \mathrm{mM}$ MES at $\mathrm{pH} 7.0,7.5$, and 8.0 for $19 \mathrm{~h}$ at $37^{\circ} \mathrm{C}$ without trypsin. The cells then were treated for $2 \mathrm{~h}$ at $37^{\circ} \mathrm{C}$ with $1.0 \mu \mathrm{g}$ of trypsin per $\mathrm{ml}$ of MEM at various $\mathrm{pH}$ levels. The trypsin treatment was terminated and the monolayers were incubated for an additional $5 \mathrm{~h}$ in trypsin-free medium at $\mathrm{pH} 8.0$ before fixation and staining.

\section{Influence of antibody on cell fusion}

Antibody suppression of cell fusion was tested with IgG fractions of rabbit anti-BCV serum and of normal rabbit serum that were obtained by protein $\mathrm{A}$-sepharose column chromatography. The ability of anti-BCV IgG to affect polykaryon formation at $37^{\circ} \mathrm{C}$ was tested by two procedures: (i) Infected cell monolayers were incubated for $6 \mathrm{~h}$ in trypsin-free MEM 
then exposed to MEM that contained antibody freshly diluted with trypsin containing medium. These monolayers were fixed and stained after $18 \mathrm{~h}$ of infection. (ii) Monolayers were infected for $9 \mathrm{~h}$ and then treated with antibody for $1 \mathrm{~h}$ in the absence of trypsin. The cells were covered with medium containing trypsin after the antibody treatment, incubated for an additional $8 \mathrm{~h}$, and then fixed.

\section{Results \\ Trypsin-dependence of $B C V$ cell fusion}

Polykaryon formation in BFS cells required the presence of trypsin at some time during virus replication. Cell fusion failed to occur in infected cultures without trypsin or when soybean trypsin inhibitor was present during trypsin
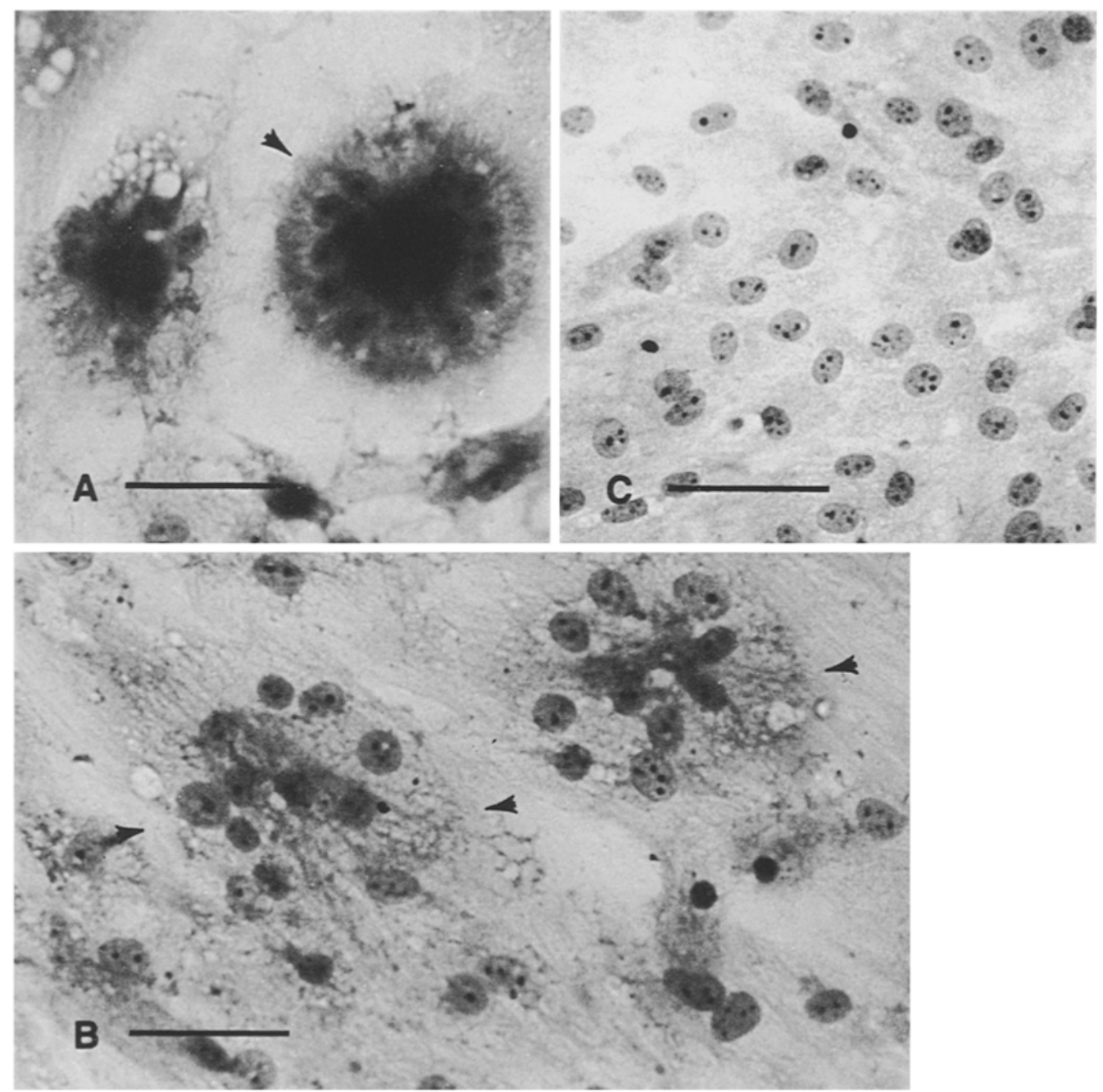

Fig. 1. Polykaryon formation in BFS cultures infected $26 \mathrm{~h}$ with BCV. A Large polykaryons (arrowhead) develop in cultures treated continuously with trypsin. B Smaller polykaryons (arrowheads) develop when the trypsin treatment is limited to a $2 \mathrm{~h}$ period (20 to $22 \mathrm{~h}$ ).

C No polykaryons develop in the absence of trypsin. Bars $=50 \mu \mathrm{m}$ 


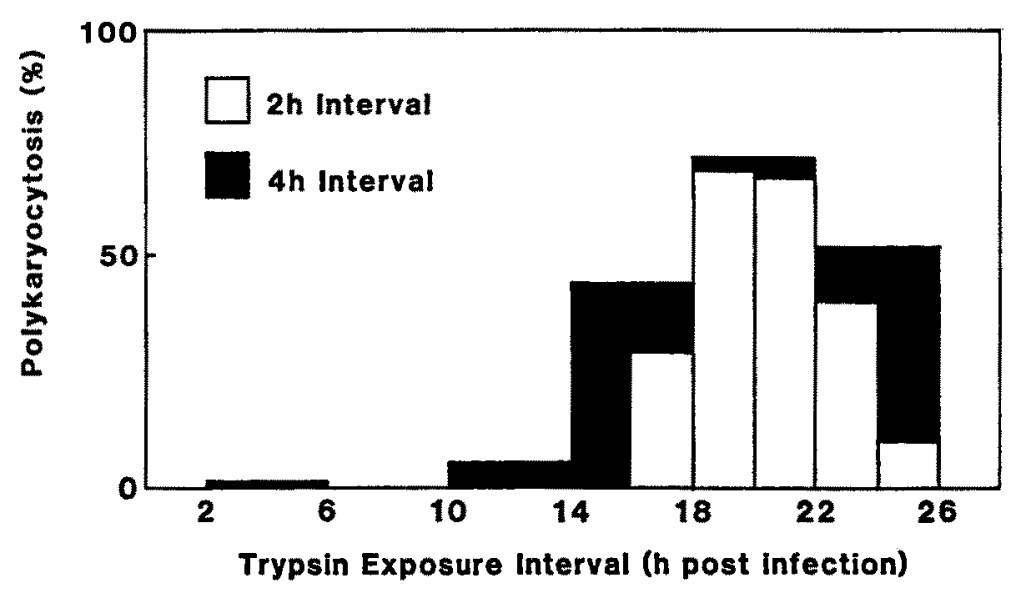

Fig. 2. Trypsin activation of BCV-induced polykaryocytosis. Infected monolayers were exposed to trypsin for a single 2 or $4 \mathrm{~h}$ interval as indicated. Maximum polykaryocytosis occurred in cultures exposed to trypsin during the period from 18 to $22 \mathrm{~h}$ post infection

treatment. Some BCV replication apparently proceeded in the absence of trypsin. The addition of trypsin to infected cultures at $3 \mathrm{~h}$ increased the yield of infectious virus by $38 \%$ and the hemagglutination titer rose. Addition of trypsin inhibitor to infected cultures decreased the infectivity yield by $39 \%$ without affecting the hemagglutination titer.

Experiments conducted to identify the period of virus infection susceptible to trypsin activation of fusion revealed that the onset of cell-to-cell fusion occurred at about $18 \mathrm{~h}$ after infection with continuous trypsin treatment. This treatment resulted in large multinucleated cells by $26 \mathrm{~h}$ (Fig. 1). A single 1 - to $2-\mathrm{h}$ trypsin treatment $10 \mathrm{~h}$ and later after infection induced formation of polykaryons. These polykaryons generally were smaller and contained fewer nuclei per cell than the fusion products of continuous trypsin treatment. Intervals of trypsin treatment that ended prior to $14 \mathrm{~h}$ after infection produced less than $6 \%$ polykaryocytosis (Fig. 2 ).

The period of maximal enhancement by trypsin treatment coincided with the observed onset of cell fusion in cultures treated continuously with trypsin.

The optimal time may be related to the appearance of a critical level of the BCV fusion proteins on the cell surface. Trypsin treatments that began at 22 or $24 \mathrm{~h}$ induced fewer polykaryons, possibly, because insufficient time was available for the fusing cells to coalesce and become visibly multinucleated.

\section{Influence of $\mathrm{pH}$ on polykaryon formation}

The greatest number of polykaryons ( 74 to 124 per field) developed in monolayers treated for a 2 or $4 \mathrm{~h}$ interval during the period between 18 and $22 \mathrm{~h}$ after infection. The brief trypsin treatment was used to test for the optimal activity level to avoid possible fluctuations in $\mathrm{pH}$ that might occur during a prolonged 
treatment. Trypsin treatment at pH 7.5 and 8.0 resulted in $20 \%$ and $39 \%$ polykaryocytosis, respectively, while treatments with media at lower or higher $\mathrm{pH}$ levels failed to support polykaryon development. This result indicated that the fusion function of $\mathrm{BCV}$ did not depend on acidic conditions.

\section{Effect of BCV antibody on cell fusion}

Fusion suppression by anti-BCV antibody was demonstrated by two different experimental protocols. Exposure at $6 \mathrm{~h}$ after infection to medium containing both trypsin and antibody reduced polykaryon formation by $50 \%$. Greater reduction occurred when infected monolayers were pretreated with the antibody. Pre-incubation with the antibody before trypsin treatment suppressed polykaryon formation by $81 \%$ over similar infected monolayers incubated with normal rabbit serum IgG. The suppression by antibody indicated that coronaviral components were involved in cell fusion.

\section{Discussion}

Trypsin treatments of BCV-infected BFS cells during the time of maximal fusion enhancement were effective only with media of $\mathrm{pH}$ levels 7.5 to 8.0. Trypsin was added in this experiment at $1.0 \mu \mathrm{g}$ per $\mathrm{ml}$, a level 5 fold greater than that needed for cell fusion with continuous treatment at $\mathrm{pH}$ 7.8. The apparent ineffectiveness of treatments at acidic $\mathrm{pH}$ levels may be related to the optimal $\mathrm{pH}$ range for trypsin activity. Further investigation is necessary to determine the full range of $\mathrm{pH}$ levels at which the viral fusion protein is active. Our results thus indicate that $\mathrm{BCV}$-induced cell fusion occurs at alkaline $\mathrm{pH}$ levels. Therefore, the fusion protein of this $\mathrm{BCV}$ is not strictly dependent on $\mathrm{pH}$ levels of 6 or less for activity.

Trypsin-treatment has a pronounced effect on $\mathrm{BCV}$ infectivity when limiting viral dilutions are employed [St. Cyr-Coats et al., submitted for publication]. This amplification of BCV infectivity is apparently unable to account for the trypsin dependence of cell fusion activity. Treatment with trypsin or trypsin inhibitor under our conditions of single cycle virus replication increased the hemagglutination titer but had only moderate effects on the yield of infectious virus. Trypsin modification of $\mathrm{BCV}$ proteins appears to activate the viral fusion factor without producing a net change in the total number of infectious particles under these conditions. The viral component responsible for trypsin-activated cell fusion is most likely expressed at the plasmalemma of the infected HRT18 cell [Payne et al., submitted for publication].

Cells infected with $\mathrm{BCV}$ fused in slightly basic environments. In this respect, the fusogenic potential of $\mathrm{BCV}$ resembles the paramyxovirus type of fusion activity. The trypsin requirement of the $\mathrm{BCV}$ fusion factor may involve a maturational cleavage of a coronaviral component analogous to the $\mathrm{F}$ protein 
of paramyxovirus $[1,10,11]$. Although the fusion protein of $\mathrm{BCV}$ has not been clearly identified, recent work revealed that trypsin treatment of BCV-infected BFS cells or virions purified from this system modifies the $185 \mathrm{kd}$ protein of the $\mathrm{BCV}$ envelope with a concommitant emergence of the $100 \mathrm{kd}$ protein, a change observable only under reducing conditions [13]. The membrane fusion activity of another coronavirus, mouse hepatitis virus, also occurs at neutral and slightly alkaline $\mathrm{pH}$ levels [15]. Like paramyxoviruses, coronaviruses may be capable of penetrating the host cell by fusion with the plasma membrane during infectious entry.

The fusion activity of alphaviruses, rhabdoviruses and orthomyxoviruses strictly requires exposure of the virus-cell complex to acidic conditions [3, 4, $17,18]$. Cell fusion can be induced at physiological $\mathrm{pH}$ by paramyxoviruses, either among cells treated under conditions of fusion from without, or among infected cells with fusion from within $[1,6]$. A specific glycoprotein component (F) of the paramyxovirus envelope is known to be involved in this membrane fusion activity. The precursor form of the $F$ protein which is expressed at the surface of nonpermissive cells can be activated by treatment with an exogenous protease that cleaves the precursor at a specific site $[10,11]$.

\section{Acknowledgements}

This work was supported by grants 80-CRSR-2-0650 and 86-CRSR-2-2871 from the United States Department of Agriculture. This paper contains parts of a dissertation submitted by H. R. Payne to Louisiana State University in partial fulfillment of the requirements for the $\mathrm{Ph}$. $\mathrm{D}$, degree.

\section{References}

1. Choppin PW, Scheid A (1980) The role of viral glycoproteins in adsorption, penetration, and pathogenicity of viruses. Rev Infect Dis 2: 40-61

2. Dimmock NJ (1982) Initial stages in infection with animal virus. J Gen Virol 59: 122

3. Edwards J, Brown DT (1986) Sindbis virus-mediated cell fusion from without is a twostep event. J Gen Virol 67: 377-380

4. Gonzalez-Scarano F, Pobjecky N, Nathanson N (1984) La Crosse bunyavirus can mediate $\mathrm{pH}$-dependent fusion from without. Virology 132: 222-225

5. Hsu M-C, Scheid A, Choppin PW (1983) Fusion of Sendai virus with liposomes: dependence on the viral fusion protein $(F)$ and the lipid composition of liposomes. Virology 126: 361-369

6. Hsu M-C, Scheid A, Choppin PW (1982) Enhancement of membrane fusion activity of Sendai virus by exposure of the virus to basic $\mathrm{pH}$ is correlated with a conformational change in the fusion protein. Proc Natl Acad Sci USA 79: 5862-5866

7. Huang RTC, Rott R, Klenk H-D (1981) Influenza viruses cause hemolysis and fusion of cells. Virology 110: 243-247

8. Kohn A (1985) Membrane effects of cytopathogenic viruses. Prog Med Virol 31: 109-167

9. Laporte J, L'Haridon R, Bobulesco P (1979) In vitro culture of bovine enteritic coronavirus (BEC). INSERM Coll 90: 99-102 
10. Rott R (1979) Molecular basis of infectivity and pathogenicity of myxoviruses. Arch Virol 59: 285-298

11. Scheid A, Choppin PW (1974) Identification of biological activities of paramyxovirus glycoproteins. Activations of cell fusion, hemolysis and infectivity by proteolytic cleavage of an inactive precursor protein of Sendai virus. Virology 57: 475-490

12. Sharpee RL, Mebus CA, Bass EP (1976) Characterization of a calf diarrheal coronavirus. Am J Vet Res 37: 1031-1041

13. St. Cyr-Coats K (1987) Bovine enteropathogenic coronavirus: the effect of the host cell and trypsin modification on the virus structure, cytopathic expression and infectivity. $\mathrm{PhD}$ dissertation, Louisiana State University, Baton Rouge, Louisiana, U.S.A.

14. Storz J, Rott R, Kaluza G (1981) Enhancement of plaque formation and cell fusion of an enteropathogenic coronavirus by trypsin treatment. Infect Immun 31: 1214-1222

15. Sturman LS, Ricard CS, Holmes KV (1985) Proteolytic cleavage of the E3 glycoprotein of murine coronavirus: activation of cell-fusing activity of virions by trypsin and separation of two different $90 \mathrm{~K}$ cleavage fragments. J Virol 56: 904-911

16. Vaananen P, Kaariainen L (1980) Fusion and hemolysis of erythrocytes caused by three togaviruses: Semliki, Sindbis, and Rubella. J Gen Virol 46: 467-475

17. White J, Kartenbeck J, Helenius A (1980) Fusion of Semliki Forest virus with the plasma membrane can be induced by low $\mathrm{pH}$. J Cell Biol 87: 264-272

18. White J, Matlin K, Helenius A (1981) Cell fusion by Semliki Forest, influenza, and vesicular stomatitis viruses. J Cell Biol 89: 674-679

19. White J, Kielain M, Helenius A (1983) Membrane fusion proteins of enveloped animal viruses. Rev Biophys 16: 151-195

Authors' address: Dr. H. R. Payne, Department of Microbiology, School of Veterinary Medicine, Louisiana State University, Baton Rouge, LA 70803-8416, U.S.A.

Received August 9, 1988 